\title{
1. Review of questions
}

\section{SECTION 1: AIMS}

113. The role of non-financial reporting: towards more effective corporate governance? The law of 24 July 1966 on trading companies had already made non-financial reporting a requirement, but was such disclosure really a "legal UFO"? This is far from certain. When, 30 years later, reporting to shareholders became an "obligation" and the principles of corporate governance arrived from the United States to make their first tentative appearance in French domestic law, ${ }^{1}$ non-financial reporting could easily have been combined with existing financial reporting to create a holistic, collective, participatory, tenable and sustainable form of corporate governance early on, that is to say, in France at least, before the passing of the Grenelle I and Grenelle II laws.

It is, however, another scenario that we will see play out, directed by none other than the European Union, which, through a whole host of communications, resolutions, recommendations and green papers, has imprinted its DNA on such reporting from the very beginning. The influence of the European Union cannot be ignored if we are to understand the specificities of non-financial reporting and, above all, the role that we hope to see it play in developing corporate governance.

It is one thing to present the content of non-financial reporting, the media used to convey it and the ways in which it can be verified, but quite another to consider whether it actually contributes to improving corporate governance, as the Union clearly wants it to do-a better world of corporate governance, as it were.

Achieving this will not be easy given the unique nature of nonfinancial reporting. ${ }^{2}$ There are high hopes for it, as though it were the only way of ensuring transparency.

\footnotetext{
1 Cf. Philippe Marini's report, Modernisation du droit des sociétés, La Documentation française, 1996.

2 "Extra"- or "non"-financial.
} 


\section{4. "A level playing field": the aims of the Proposal of 16 April 2013} for a Directive of the European Parliament and of the Council. This proposal is the latest in a long line of signals sent by the European Union in relation to non-financial reporting and shares the same aim of "strengthening" and "improving" transparency. It sets "a requirement for certain large companies to disclose relevant non-financial and diversity information, ensuring a level playing field across the EU". ${ }^{3}$

What role will the European Securities and Markets Authority (ESMA) play in this area during this period of "regulatory activism"?

\section{SECTION 2: PREREQUISITES}

115. High-quality, accessible non-financial reporting: "key requirements for good corporate governance". In practical terms, the role of CSR in corporate governance is reflected in the existence of nonfinancial committees ( 27 per cent of companies surveyed explicitly addressed these matters at board level $)^{5}$ and the linking of the performance-related element of executive directors' pay to non-financial performance criteria.

Non-financial reporting is a somewhat rare example of direct international influence on corporate law. ${ }^{6}$ The environment of course predates both companies and scientific advances and yet, unlike other branches of law, ${ }^{7}$ corporate law integrated this concept late on. The requirement for

3 Proposal of 16 April 2013 for a Directive of the European Parliament and of the Council amending Council Directives 78/660/EEC and 83/349/EEC as regards disclosure of non-financial and diversity information by certain large companies and groups, $\operatorname{COM(2013)~} 207$ final; http://eur-lex.europa.eu/legalcontent/EN/TXT/PDF/?uri=CELEX:52013PC0207\&from=EN; see "Explanatory Memorandum", p. 2.

4 P.-H. Conac, V. Caillat, "De CESR à l'ESMA: le Rubicon est franchi”, Bull. Joly Bourse, November-December 2010, p. 500, esp. p. 508.

5 Report by the Autorité des Marchés Financiers (the French financial markets regulator) dated 2 December 2010, cf. point 235 below.

6 Cf. in particular the United Nations Conference on the Human Environment held in Stockholm in 1972, the World Charter for Nature (1992) and Art. 11 of the Treaty on the Functioning of the European Union, which refers to the promotion of "sustainable development". The recognition of this notion is an example of the positive influence of globalisation.

7 D. Voinot, "Le sort des créances dans la procédure collective, L'exemple de la créance environnementale", RTD com., 2001, p. 581 et seq., esp. p. 582; on this point, cf. also the discussion paper published by the International Integrated Reporting Committee (IIRC) in September 2011, http://theiirc.org/wp-content/ 
environmental reporting in corporate law is new ${ }^{8}$ as the law of 24 July 1966 did not provide for this type of disclosure. However, it is above all the content of such reporting that is new and not the modern means of sharing such information. ${ }^{9}$

Reporting to shareholders, the key idea underpinning the law of 24 July $1966,{ }^{10}$ therefore gave way to the requirement for transparency enshrined in the law on "new economic regulations" (loi relative aux nouvelles régulations économiques, also known as the "NRE" Law). ${ }^{11}$ This desire for transparency is guided by a broader moralising trend (individuals holding more than one post simultaneously, publication of the remuneration and benefits of all kinds paid to company officers, including stock options).

These two types of reporting-social and environmental-are "key requirements for good corporate governance" 12 and as such are vital to

uploads/2011/09/IR-Discussion-Paper-2011_spreads.pdf, in which the author highlights the transition that has taken place from the company to the surrounding community. See also, P. Lascoumes, L'éco-pouvoir, environnements et politiques, La Découverte, 1994, p. 116; M. Prieur, Droit de l'environnement, 4th edn, Précis Dalloz, 2000, no. 55, p. 5; M. Rémond-Gouilloud, Du droit de détruire, Essai sur le droit de l'environnement, PUF, 1998; M. Despax, Droit de l'environnement, Litec, 1980; M. Varella, L'inégalité Nord-Sud et la construction juridique du développement durable dans le droit international, thesis, Paris I, Hermitte (supervisor), 2002.

8 J. Robertson, Changer l'économie ou La nouvelle économie du développement durable: une étude à l'intention des responsables politiques européens, Éditions Apogée, Luxembourg, Publications Office of the European Union, 2000; F. Caballero, Essai sur la notion juridique de nuisance, pref. by J. Rivero, LGDJ, 1980 , p. 20 et seq. on the notion of an "ecological public order"; P. Didier, "Une définition de l'entreprise", in Le droit privé français à la fin du xx $x^{e}$ siècle, Études offertes à P. Catala, Litec, 2001, p. 849.

9 Cf. Y. Guyon, "Les dispositions du décret du 3 mai 2002 relatives aux assemblées générales d'actionnaires", Rev. sociétés, 2002.421, on the provisions that govern the use of telecommunications technologies at shareholders' meetings.

10 I. Urbain-Parléani, M. Boizard, "L'objectif d'information dans la loi du 24 juill. 1966", Rev. sociétés, 1996, 447.

11 French Commercial Code, Art. L. 225-102-1.

12 Art. 53 of the Grenelle I Law of 3 August 2009 states that "The quality of reporting on the way in which companies take into account the social and environmental consequences of their activities and access to such information are key requirements for good corporate governance"; F.-G. Trébulle, "Le développement de la prise en compte des préoccupations environnementales sociales et de gouvernance", Dr. sociétés, January 2009, Commentaire 1. 
sustainable corporate governance. ${ }^{13}$ As indicated in recital 10 of Directive 2006/46/EC and expressly provided for in Article 53 of the "Grenelle I" Law 2009-967 of 3 August 2009, ${ }^{14}$ "The quality of reporting on the way in which companies take into account the social and environmental consequences of their activities and access to such information are key requirements for good corporate governance". ${ }^{15}$

116. Equal access to information at an affordable cost. The Global Reporting Initiative (GRI) published a study on the cost of sustainability reports. ${ }^{16}$ Excluding the oil company Shell, which posted a record cost of $\$ 3$ million, these costs range from $\$ 105,000$ to $\$ 1$ million, the average being $\$ 308,000$. Insurance will account for a large part of this and, once again, the cost of this cannot be ignored. While the 1966 law advocated shareholder equality, the highly technical nature of the new form of reporting introduced under the NRE Law risks creating inequality between companies. Furthermore, shareholder associations could analyse such information from a purely consumerist perspective. It should be remembered that the distribution of dividends must not be compromised by such a cost.

Access to non-financial information will be key to ensuring the effectiveness of "participatory corporate governance". It is therefore not surprising that it is deemed almost "sacred", particularly in the case of environmental reporting. Article L. 110-1, II, 4 of the Environmental Code describes

the principle of participation, according to which everybody has access to information relating to the environment, including information relating to hazardous substances and activities, and whereby the public is involved in the process regarding the development of projects that have a major impact on the environment or on town and country planning.

Is this the ultimate paradox? "The law deals with relations between men, while the sciences know not men but numbers. If jurists wish to establish laws on the basis of numbers, then they must spurn the human element". ${ }^{17}$ Although CSR forms part of this legal mission, it humanises

13 C. Malecki, "Le Grenelle II et la gouvernance d'entreprise sociétale", Bull. Joly Sociétés, Éclairage, 2010, p. 704.

14 Programme Law 2009-967 of 3 August 2009 on the implementation of the "Grenelle de l'environnement" initiative, JO of 5 August 2009.

15 Art. 53 Directive 2006/46/EC, emphasis added.

16 http://www.globalreporting.org.

17 G. Ripert, Les forces créatrices du droit, Paris, LGDJ, 1955, no. 15, p. 43. 
corporate governance while at the same time using numbers to make it more effective.

\section{Understanding non-financial reporting to unlock "non-financial} knowledge". Non-financial reporting will require technical skills if we are to understand it in all its complexity. It is elitist in that it performs a "balancing act" between social, environmental and societal issues and must be approached from a range of different perspectives in order to be fully understood. Who could claim that they are able, for example, to read between the-often self-congratulatory and inevitably virtuouslines and grasp exactly what is meant by "societal obligations"?

\section{SECTION 3: CHARACTERISTICS}

118. Reporting with a "psychological" dimension. Non-financial reporting comprises essential, highly sensitive information that is a source of not only trust but also mistrust and both reflects and is a condition for a company's performance. Such non-financial information ${ }^{18}$ plays an important role in relation to shareholders, who will be more sensitive ${ }^{19}$ to such information given that social issues are sometimes easier to decipher than financial information, the focal point of the law of 24 July on trading companies. As Yves Guyon has pointed out, "From a practical perspective, a company cannot hope to attract and retain shareholders unless it earns their trust by implementing a 'glass house' policy on transparency". ${ }^{20}$ Non-financial reporting will play an increasingly important role in relation to stakeholders. While shareholders are concerned with financial performance, consumers want more information on the social and environmental performance of the companies from whom they buy their consumer goods. Their expectations are decisive at European level. ${ }^{21}$ The same is true of, for example, non-governmental

18 As opposed to "financial information".

19 On this point, cf. Ph. Didier, "Here, the requirement to disclose nonfinancial information is a means of raising awareness, of persuasion", "Quelles normes pour la RSE?", in F.-G. Trébulle and O. Uzan (eds), Responsabilité sociale des entreprises, Regards croisés Droit et Gestion, Economica, "Études juridiques" collection, 2011, p. 91 et seq., esp. 99.

20 Y. Guyon, Droit des affaires, volume 1, Droit commercial et Sociétés, 10th edn, Economica, 1998, no. 294, p. 293.

21 Cf. the Communication from the Commission to the European Parliament, the Council, the European Economic and Social Committee and the Committee of the Regions of 27 October 2010 (COM(2010) 608 final/2) entitled "Towards a 
organisations working on environmental issues: the strength of their reactions can take the form of reputational attacks.

119. Reporting under the constant pressure of the European Union's "regulatory drive". Since 2011, non-financial reporting has become more accurate and in-depth and has had a greater impact, to such an extent that the European Commission has launched an extensive consultation on changes to such reporting. This is reflected in the summary of responses to the public consultation on the publication of non-financial information by companies, which was published in April 2011.22 The European Union is proposing an effective roadmap for standardising non-financial information on the basis of extensive studies analysing the Environmental, Social and Governance (ESG) standards used by major European companies. ${ }^{23}$ The Union is fast-tracking its initiative on nonfinancial reporting with the unveiling of the "Responsible Businesses' Package" by the European Commission on 25 October 2011. Whereas in France it is sometimes difficult to understand what is meant by the "simplification" 24 of such information, reflecting a piecemeal, stratified, surgical, back-and-forth approach to legislation, the Union is not deviating from its course. It has continued to emphasise the importance of transparency in non-financial reporting. ${ }^{25}$ Similarly, although Member States do have the power to exempt SMEs from the requirement to publish non-financial information in accordance with the Fourth Council

Single Market Act: for a highly competitive social market economy, 50 proposals for improving our work, business and exchanges with one another" and available online at http://ec.europa.eu/internal_market/smact/docs/single-market-act_fr.pdf.

22 http://ec.europa.eu/internal_market/consultations/docs/2010/non-financial_ reporting/summary_report_en.pdf.

23 Cf. "An analysis of Policy References made by large EU Companies to Internationally Recognised CSR Guidelines and Principles", March 2013, http:// www.upj.de/fileadmin/user_upload/MAIN-dateien/Infopool/Forschung/eu_guide linesprinciples_2013.pdf.

24 In reference to the Warsmann II Law of 22 March 2012.

25 Cf. the Commission Communication of 25 October 2011, "A renewed EU strategy 2011-14 for Corporate Social Responsibility”, COM(2011) 681 final, http://ec.europa.eu/enterprise/policies/sustainable-business/files/csr/new-csr/act_ fr.pdf; cf. L. Roglev, J. Beckhard, V. Becker, "Responsabilité des entreprises: une compliance à l'européenne?”, RLDA, January 2012, no. 67, p. 10. 
Directive 78/660/EEC on the annual accounts of certain types of companies, amended by Directive 2003/51/EC of 18 June 2003, the trend continues to remain in favour of publishing such information. ${ }^{26}$

120. Reporting: a symbol of globalisation. Non-financial reporting symbolises the coming together of business, globalisation and technology. It crystallises questions raised by private international law, particularly in the context of groups of companies. The vocabulary used reflects the dominance of the English-speaking world in drawing up European directives since the late 1990s. Although globalisation seems to have been called into question by certain economists or, at least, to have run its course, non-financial reporting will essentially convey information that is most often interpreted on the basis of international standards. For example, we can point to the ILO and the implementation of CSR in Africa, faced in particular with the current absence in the law set by the Organisation for the Harmonisation of Business Law in Africa (OHADA) of a holistic vision of CSR. Its role will depend on its clarity, reliability and how stakeholders will make use of it.

\section{SECTION 4: RISKS}

121. A breach of corporate secrecy? Extending the scope of nonfinancial reporting and the ease with which it can be accessed using new technologies makes it even more difficult to reconcile transparency with the need for corporate secrecy. ${ }^{27}$ The key idea underpinning the law of 24 July 1966 on trading companies, and later reinforced by the NRE Law, was the drive towards ever more disclosure (to shareholders, employees and third parties). In English law, the term "disclosure" itself reflects this idea of "baring all". Companies could be tempted to publish a cursory description of this list of social information. In particular, the

26 Cf. The summary of responses op. cit. to the public consultation on the publication of non-financial information by companies, published in April 2011, http://ec.europa.eu/internal_market/consultations/docs/2010/non-financial_ reporting/summary_report_en.pdf.

27 Cf. French Commercial Code, Art. L. 225-100-3-9 taken from the law of 31 March 2006, C. Malecki, "La loi du 31 mars 2006 relative aux OPA et l'information des actionnaires et des salariés", D. 2006, Cah. dr. aff., p. 2314; Art. L. 225-37, paragraph 5 of the French Commercial Code states that "Directors and any other person called upon to attend board meetings are bound not to disclose information that is confidential in nature and is indicated as such by the chair of the board of directors." 
"report or explain" rule ${ }^{28}$ poses this risk, even though non-financial reporting seems virtuous in many respects: companies would be more socially responsible, sustainable and better able to take into account social, societal and environmental risks as a result.

\section{SECTION 5: OPPORTUNITIES}

122. New avenues for "European-style" sustainable corporate governance. Although non-financial reporting naturally provokes some critical reactions, it is nonetheless helping to bring about a consensus. Comprehensive studies, particularly those carried out in the United States and United Kingdom, have already shown that it undeniably plays a role in the development of corporate governance: it allows for more effective corporate governance. These theoretical studies are interesting on this point, particularly as they have greater hindsight and raise many questions (such as what effectiveness can be achieved in practice?). ${ }^{29}$ The notions of "transparency" and "obligation of disclosure" have allowed for a new, more regulated ${ }^{30}$ and even "meta-regulated" approach to corporate governance. English theorists have already questioned the real contribution of non-financial reporting, ${ }^{31}$ something that would be of relevance to

28 The visionary Y. Guyon had previously highlighted the challenge of reconciling the need for disclosure with corporate secrecy: "Many directors still use corporate secrecy as justification for providing the least possible information", in Droit des affaires, above n. 20, no. 294, p. 293; cf. also C. Gavalda, "Le secret des affaires", in Mélanges R. Savatier, Dalloz, 1965, p. 263 et seq.; Y. Paclot, "Les diverses facettes du secret des affaires", Dr. et patr., March 2002, p. 70, esp. p. 75: "corporate secrecy, as a general principle of law, does not exist."

29 Cf., in particular, A. Kolk, "Sustainability, Accountability and Corporate Governance: Exploring Multinationals' Reporting Practices”, Business Strategy and the Environment, 2008, Vol. 17(1), pp. 1-15; C. Deegan, "The Legitimizing Effect of Social and Environmental Disclosures-A Theoretical Foundation", Accounting, Auditing \& Accountability Journal, 2002, Vol. 15(3), p. 282.

30 D. Hess, "Social Reporting and New Governance Regulation: The Prospects of Achieving Corporate Accountability through Transparency", Business Ethics Quarterly 2007, Vol. 17(3), p. 455; K. Campbell and D. Vick, "Disclosure law and the market for corporate social responsibility", in The New Accountability, Corporate Social Responsibility and the Law, D. McBarnet, A. Voculescu and T. Campbell (eds), Cambridge University Press, 2007, pp. 241-78.

31 Cf. O. Aiyegbayo and Ch. Villiers' very interesting article, "The Enhanced Business Review: Has it Made Corporate Governance More Effective?", Journal of Business Law, 2011, Issue 7, pp. 699-724, and the various references. 
French domestic law if, under the influence of the European Union, we were to implement Stakeholder Theory. ${ }^{32}$

The European Union is openly expressing its high hopes for nonfinancial reporting, seeing it as a chance for businesses to better manage opportunities and improve their non-financial performance. It believes that investors will be able to "take better account of sustainability considerations and long term performance". 33

Such reporting also demands an analysis of the "decision-making criteria" that help to ensure better corporate governance. ${ }^{34}$ It serves as a salutary reminder of the crucial importance of accounting law. ${ }^{35}$ It will spur shareholders to action, engage institutional investors and serve as ammunition for stakeholders. It will be the "lifeblood" of a sustainable corporate governance that must perform, ${ }^{36}$ as well as a window onto and vehicle for a company's reputation, good or bad. ${ }^{37}$ Analysing such information, which can at times seem tiresome given that it is made up of a series of highly technical elements, in reality throws the doors of corporate governance wide open to the constraints and opportunities of the twenty-first century. This century will be one of technological and biological progress, as well as climate-related challenges. The economic and industrial world has in reality become smaller, more accessible and more vulnerable, too.

32 Cf. sections 172 and 417 of the Companies Act; S.M. Cooper, D.L. Owen, "Corporate social reporting and stakeholder accountability: The missing link", Accounting, Organizations and Society, 2007, Vol. 32, pp. 649-67.

33 Proposal op. cit., "Explanatory Memorandum", p. 2.

34 Cf. the study by the Institut Français des Administrateurs (IFA) entitled "Structure de gouvernance de l'entreprise: critères de décisions", http://static. talkspirit.fr/voxfemina/media/IFA \%20Janvier\%202013.pdf, January 2013.

35 The EU is making headway by means of "accounting" directives, particularly the Fourth Council Directive 78/660/EEC of 25 July 1978 on the annual accounts of certain types of companies and the Seventh Council Directive 83/349/EEC of 13 June 1983 on consolidated accounts of companies with limited liability; cf. the Single Accounting Directive 2013/34/EU of 26 June 2013, OJEU, 29 June 2013, no. L. 182/19.

36 A. Hassan and E. Ibrahim, "Corporate Environmental Information Disclosure: Factors Influencing Companies' Success in Attaining Environmental Awards", Corporate Responsibility and Environmental Management, 2012, Vol. 19, pp. 32-46. DOI: 10.1002/csr.278.

37 J. Hasseldine, A.I. Salama and J.S. Toms, "Quantity versus quality: the impact of environmental disclosures on the reputations of UK Plcs", The British Accounting Review, 2005, Vol. 37, pp. 321-48. 
Are there any shadows in this otherwise idyllic picture? Non-financial reporting will doubtless have its detractors and questions will inevitably be raised in the background. Is it so expensive that we must exempt small businesses at a time when the Union is aware of the role of SMEs in this area? Is it only large, and indeed very large, companies that must be accountable? ${ }^{38}$ Will such reporting really be a tool for promoting better corporate governance? Will it help companies to meet the "requirement for transparency"? On the contrary, will it not serve as an opportunity to leave out certain sensitive information, particularly through the implementation of a version of "sustainability compliance" or "sustainability reporting" 39 that has been stripped down to almost nothing?

123. The consequences for fiscal reporting. The requirement for transparency is reflected in the various branches of law. Tax law could be influenced by this movement sparked by CSR that forms part of sustainable corporate governance-not only in terms of "socially responsible" behaviour in relation to taxation, which would have to be defined, but also depending on the recipients of this information, particularly stakeholders. CSR could have a role to play in relation to tax transparency: ${ }^{40}$ listed companies could be required to publish a specific statement on certain "socially responsible" tax-related behaviour based on long-term criteria. More explicitly, the European Parliament Resolution of 6 February $2013^{41}$ stresses the need to "combat tax avoidance".

124. The link between non-financial reporting and developments in corporate governance. Non-financial reporting is not only the guiding

38 C. Malecki, "La transparence environnementale à la charge des sociétés", in V. Magnier and L. Fonbaustier (eds), Développement durable et entreprise, Dalloz, "Thèmes et Commentaires" collection, Actes, 2013, p. 107 et seq.

39 Cf. points 174 and 206 et seq. below.

40 Cf. the reflections and prospects envisaged by D. Gutmann in Droit fiscal, 4th edn, LGDJ, Domat droit privé, 2013, no. 1021, p. 771 et seq., who describes the need to "strengthen the processes used to audit tax-related decisions within companies" and to "reinforce the requirement for businesses to be transparent in relation to their tax behaviour", as well as the various references; M. Chadefaux, "Les instruments fiscaux de la RSE", RLDA, July-August 2013, no. 84, p. 86 et seq.

41 European Parliament Resolution of 6 February 2013 on "Corporate social responsibility: accountable, transparent and responsible business behaviour and sustainable growth" [2012/2098 (INI)], http://www.europarl.europa.eu/sides/get Doc.do?pubRef=-//EP//TEXT+TA+P7-TA-2013-0049+0+DOC+XML+V0//EN, point 22 . 
principle but also the cornerstone of the structure that is sustainable corporate governance. It will justify recognition of the legitimacy of a particular stakeholder's interest and will help to create new obligations in business transactions. An analysis of non-financial accounting therefore offers food for thought when considering the transition from the "old school" corporate governance towards a "new school" sustainable corporate governance that is fit for the twenty-first century. It is the principal theme.

\section{SECTION 6: TERMINOLOGICAL ISSUES: FROM NON-FINANCIAL TO "JUST" FINANCIAL}

\section{Non-financial reporting that is also and above all financial.} Extra-financial, or rather, "non-financial" reporting, to use the term recently adopted by the European institutions, is unique in more than one respect. To begin with, it has played a "historic" role, if we can use this expression given that CSR has only very recently appeared in French corporate law, albeit decisively and swiftly. It is through this type of reporting that listed companies have been made aware of the now far-reaching constraints imposed by CSR. Second, it has transformed from a dual concept (social and environmental) to a unique triple one (social, environmental and "societal"). However, the terms used to refer to it ("extra-" or "non-financial" reporting) cannot hide the reality that it is also and above all financial (as can be seen in the desirable movement towards integrated reporting). Indeed, non-financial reporting has significant financial consequences, as is highlighted in the European Parliament Resolution of 6 February 2013: "the use of the term 'non-financial' should not disguise the very real financial consequences for business of social, environmental and human rights issues". ${ }^{42}$ The resolution also states that "corporate sustainability reporting integrated into financial accounts will become the global norm within less than a decade". ${ }^{43}$ The findings of research done by the International Integrated Reporting Committee (IIRC) are similarly along these lines.

42 European Parliament Resolution of 6 February 2013 on corporate social responsibility: promoting society's interests and a route to sustainable and inclusive recovery [2012/2097 (INI)]; http://www.europarl.europa.eu/sides/ getDoc.do?pubRef=-//EP//TEXT+PV+20130206+ITEM-007-11+DOC+XML+ $\mathrm{V} 0 / / \mathrm{EN}$, point 71.

43 Resolution op. cit., recital D. 
126. Terminology. Although social, environmental and societal reporting is often referred to as "extra-financial reporting", the term used by the European institutions is "non-financial reporting". We will use the latter term here. 